\title{
Persepsi Tenaga Kesehatan terhadap Penggunaan Alat Pelindung Diri dan Kejadian Kecelakaan Akibat Kerja di Salah Satu Rumah Sakit di Kota Bandung
}

\author{
Atri Laranova1, Irvan Afriandi ${ }^{2}$, Yuni Susanti Pratiwi ${ }^{3}$ \\ ${ }^{1}$ Fakultas Kedokteran Unversitas Padjadjaran \\ ${ }^{2}$ Departemen Ilmu Kesehatan Masyarakat, Fakultas Kedokteran, Universitas Padjadjaran \\ ${ }^{3}$ Departemen Anatomi, Fisiologi dan Biologi Sel, Fakultas Kedokteran, Universitas Padjadjaran
}

\begin{abstract}
Abstrak
Tenaga kesehatan berperan dalam meningkatkan derajat kesehatan masyarakat dan berhak mendapatkan jaminan kesehatan dan keselamatan kerja. Penelitian sebelumnya melaporkan kecelakaan kerja yang sering terjadi di rumah sakit adalah tertusuk jarum, teriris pisau, terluka dan terpercik cairan tubuh. Kejadian tersebut banyak yang belum terlaporkan karena padatnya jadwal pelayanan kesehatan dan rendahnya persepsi terhadap risiko terpapar infeksi. Rendahnya persepsi dan tingginya risiko kejadian kecelakaan kerja menjadi tujuan penelitian ini dilakukan untuk mengetahui hubungan antara persepsi tenaga kesehatan terhadap penggunaan alat pelindung diri dengan kejadian kecelakaan akibat kerja. Metode Penelitian dilakukan dengan metode analitik dan desain potong lintang yang melibatkan 102 tenaga kesehatan yang dipilih dengan teknik simple random sampling di salah satu rumah sakit di Kota Bandung pada bulan Oktober hingga November 2016. Variabel yang diteliti meliputi persepsi terhadap penggunaan alat pelindung diri dan kejadian kecelakaan akibat kerja. Data diambil melalui instrumen kuesioner kemudian dilakukan analisis data dengan menggunakan uji Chisquare dan Uji Spearman Correlation. Hasil tidak terdapat hubungan yang signifikan antara variabel yang diteliti dengan nilai $r=-0,085$ dan $p=0,395$. Pembahasan tidak ada hubungan antara persepsi tenaga kesehatan terhadap penggunaan alat pelindung diri dengan kejadian kecelakaan akibat kerja. Terdapat faktor-faktor lain yang dapat memengaruhi kepatuhan dalam penggunaan alat pelindung diri dan kejadian kecelakaan kerja.
\end{abstract}

Kata Kunci : APD, KAK, Persepsi, Tenaga kesehatan.

\section{Perceptions of Health Care Workers toward Personal Protective Equipment Usage and Prevalence of Occupational Accident in One of Hospital at Bandung}

\begin{abstract}
Health care workers hold important roles in improving community health and had been right toward occupational health and safety insurance. Researches reported cases of needle stick injuries, blade cuts, wounded, also contact with blood and other bodily fluids. More of such cases were not reported due to busy schedules of medical services and low level of perceptions of infection risks. The low level of perceptions and high level of occupational accidents became the aim of this study, which is to evaluate the correlation between perceptions of health care workers toward personal protective equipment usage with prevalence of occupational accidents. Methods this study was designed as an analytic cross sectional study, which included 102 health care workers who were selected with simple random sampling technique in one of hospital at Bandung from October to November 2016. Variables of interest were perception toward the use of personal protective equipment and incidence of occupational accidents. Data were collected using self-administered questionnaires and then data were analized using Chi-square test and Spearman-Correlation test. The results there is no significant correlation between variabels of interest with value of $r=-0,085$ and $p=0,395$. Discussion there is no correlation between perceptions of health care workers toward personal protective equipment usage with prevalence of occupational accidents. There are other factors that affect to adherence toward personal protective equipment usage and occupational accidents in hospital.
\end{abstract}

Keyword : Health care workers, Occupational accidents, PPE, Perception.

Korespondensi:

Atri Laranova

Fakultas Kedokteran Universitas Padjadjaran

Jl. Raya Bandung-Sumedang KM 21 Jatinangor, Sumedang

Mobile : 081313105247

Email : atrilaranova@gmail.com 


\section{Pendahuluan}

Tenaga kesehatan memiliki peranan penting dalam meningkatkan kualitas pelayanan kesehatan yang maksimal kepada masyarakat untuk mewujudkan derajat kesehatan yang setinggi-tingginya sebagai investasi bagi pembangunan sumber daya manusia yang produktif secara sosial dan ekonomi serta sebagai salah satu unsur kesejahteraan umum. ${ }^{1}$

Peningkatan derajat kesehatan bukan hanya ditujukan kepada masyarakat tetapi juga untuk tenaga kesehatan yang berperan sebagai pemberi pelayanan kesehatan sehingga rumah sakit berkewajiban menyehatkan para tenaga kerjanya. Upaya tersebut dilaksanakan secara integrasi dan menyeluruh untuk mengurangi risiko terjadinya penyakit dan kecelakaan akibat kerja. ${ }^{2}$ Hal ini sesuai dengan Permenkes RI nomor 66 tahun 2016 yang mengatakan bahwa keselamatan dan kesehatan kerja rumah sakit adalah segala kegiatan untuk menjamin dan melindungi keselamatan dan kesehatan bagi sumber daya manusia rumah sakit, pasien, pendamping pasien, pengunjung, maupun lingkungan rumah sakit melalui upaya pencegahan kecelakaan kerja dan penyakit akibat kerja di rumah sakit. Berdasarkan data dari WHO tahun 2010 menyatakan bahwa 59 juta petugas kesehatan telah terpapar dengan berbagai macam bahaya setiap harinya. ${ }^{3}$ Terpaparnya tenaga kesehatan dengan berbagai potensi yang berbahaya dapat menimbulkan penyakit infeksi akibat kecelakaan kerja. Pada tahun 2010 dilaporkan bahwa injeksi yang tidak aman menimbulkan kejadian infeksi HIV 33.800 kasus, hepatitis B 1,7 juta kasus dan hepatitis C 315.000 kasus, sedangkan seseorang yang tertusuk jarum suntik memiliki risiko infeksi $30 \%$ HBV, $1,8 \%$ HCV dan $0,3 \%$ HIV., ${ }^{2,4}$ Penelitian yang dilakukan pada salah satu rumah sakit di Shiraz, Iran, menyatakan bahwa prevalensi tertusuk jarum pada perawat adalah $76 \%$, tetapi $60,2 \%$ tidak ada laporan karena padatnya jadwal pelayanan kesehatan $(46,7 \%)$ dan rendahnya persepsi terhadap risiko terpapar infeksi $(37,7 \%) .{ }^{5}$

Penelitian juga dilakukan di provinsi Jawa Barat, diantaranya penelitian yang dilakukan oleh Kusman Ibrahim di Rumah Sakit menyatakan bahwa kajadian akibat kerja seperti tertusuk jarum $(32,8 \%)$, teriris pisau $(3,3 \%)$, terluka $(24,5 \%)$ dan terpercik darah dan cairan tubuh lainnya $(39,4 \%)$, rata-rata $23 \%$ terjadi pada waktu kerja di pagi hari. ${ }^{6}$ Laporan dari penelitian lain yang dilakukan di salah satu Rumah Sakit Pendidikan juga menyatakan bahwa tenaga kesehatan mengalami luka akibat benda tajam sebesar $48 \%$ dan terpercik cairan sebesar $62 \%$. Persepsi hambatan untuk impelementasi universal precaution setara dengan rendahnya suplai alat pelindung diri
(73\%) dan bekerja di ruang darurat.

Penelitian-penelitian di atas dapat disimpulkan bahwa faktor-faktor yang dapat memengaruhi kejadian kecelakaan tersebut diantaranya kurangnya pengetahuan mengenai bahaya dari pekerjaan, kesadaran dan komitmen dalam penggunaan alat pelindung diri, ketersediaan alat pelindung diri yang memadai serta belum adanya sosialisasi atau prosedur operasional standar yang jelas berkaitan dengan kesehatan dan keselamatan kerja di rumah sakit. Pentingnya penggunaan alat pelindung diri berkaitan dengan persepsi tenaga kesehatan yang berdampak terhadap terjadi atau tidak terjadinya suatu kesalahan dalam bekerja yang menimbulkan kejadian kecelakaan akibat kerja dan penyakitpenyakit infeksi yang berbahaya. Oleh karena itu, penelitian ini dilakukan untuk mengetahui hubungan persepsi tenaga kesehatan terhadap penggunaan alat pelindung diri dengan kejadian kecelakaan akibat kerja di salah satu rumah sakit di Kota Bandung. Selain itu, melalui penelitian ini diharapkan dapat memberikan gambaran mengenai penyusunan stategi dalam peningkatan kesehatan dan keselamatan kerja di rumah sakit.

\section{Metode}

Penelitian dilakukan pada bulan Oktober hingga November 2016. Berdasarkan surat persetujuan Komite Etik Penelitian Kesehatan Fakultas Kedokteran Universitas Padjadjaran Bandung, penelitian dilakukan dengan studi analitik dengan desain potong lintang (cross sectional). Data diambil langsung dari responden dengan menggunakan keusioner yang terdiri dari 2 kuesioner diantaranya kuesioner mengenai persepsi terhadap penggunaan alat pelindung diri (APD) dan pengalaman kecelakaan akibat kerja (KAK) serta identitas responden. Kuesioner persepsi merupakan hasil modifikasi kuesioner dari penelitian "Development of A Health Belief Model Based Instrument to Assess Worker Beliefs about Using Personal Protective Equipment" oleh Jack M. Wall pada tahun 2009, ${ }^{8}$ kemudian diterjemahkan ke dalam Bahasa Indonesia oleh peneliti dan belum divalidasi.

Kuesioner dalam penelitian ini didistribusikan kepada tenaga kesehatan di salah satu rumah sakit yaitu Rumah Sakit Khusus Ibu dan Anak di Kota Bandung. Rumah sakit ini terpilih sebagai tempat penelitian karena belum ada penelitian mengenai persepsi dan kejadian kecelakaan akibat kerja yang dilakukan di rumah sakit khusus. Responden penelitian ini dipilih dengan teknik simple random sampling. Tenaga kesehatan yang terpilih sebagai responden harus memenuhi 
kriteria inklusi yaitu bekerja minimal 1 bulan terakhir sebelum dilakukan penelitian, sehingga diperoleh 102 responden yang merupakan tenaga kesehatan (tenaga medis, kebidanan, keperawatan dan laboratorium) di rumah sakit tersebut. Namun demikian, jumlah sampel yang telah diperoleh tidak memenuhi jumlah sampel minimum karena responden menolak dan tidak hadir saat penelitian serta pengisian kuesioner yang tidak lengkap (kriteria eksklusi).

Kuesioner persepsi terhadap penggunaan alat pelindung diri diukur dengan memberikan 36 pernyataan yang dibagi menjadi 6 kelompok jenis persepsi berdasarkan konsep Health Belief Model. ${ }^{8,9}$ Pernyataan tersebut terdiri dari 10 pernyatan negatif (skor 0 untuk sangat setuju dan skor 3 untuk tidak setuju) dan 26 pernyataan positif (skor 3 untuk sangat setuju dan skor 0 untuk tidak setuju). Pernyataan negatif terdapat pada nomor $4,9,12,16,19,21,24,26,32$, dan 34 dalam kuesioner. Kuesioner pengalaman kecelakaan akibat kerja dibuat berbentuk tabel yang terdiri dari jenis-jenis kecelakaan yang kemungkinan terjadi di rumah sakit untuk mempermudah pengisian oleh responden. Jenis-jenis kecelakaan akibat kerja yang diteliti diambil dari berbagai literatur, diantaranya teriris benda tajam, tertusuk jarum suntik, terpercik darah dan cairan tubuh lain, mata tersemprot zat kimia, mata kemasukan benda asing, terpeleset, terjatuh, terbentur, terjepit, dan terkena benda panas. ${ }^{5,6,7,10,11,12}$

Analisis data yang dilakukan dalam penelitian ini diantaranya analisis data deksriptif, uji Chisquare untuk 36 pernyataan mengenai terhadap persepsi penggunaaan alat pelindung diri sebagai variabel bebas dan kejadian kecelakaan akibat kerja sebagai variabel terikat dan uji Spearman Correlation untuk hipotesis dalam penelitian karena data terdistribusi tidak normal (nilai $p$ uji Kolmogorov-Smirnov kurang dari 0,05). Data sudah dimasukkan ke dalam Microsoft Excel 2013 kemudian dilakukan analisis dengan menggunakan Statistic Application Software yaitu Statistical Product and Service Solution (SPSS).

\section{Hasil}

Responden dalam penelitian ini mayoritas berjenis kelamin perempuan $(94,1 \%)$ dan memiliki pendidikan terakhir diploma $(79,4 \%)$. Responden juga mayoritas berprofesi sebagai bidan $(46,1 \%)$ dan perawat $(44,1 \%)$ serta sebagian besar responden berkerja di unit pelayanan rawat inap $(50 \%)$. Pengalaman responden bekerja dalam median 6 tahun. Responden yang mengikuti pelatihan mengenai alat pelindung diri kurang dari setengahnya yaitu 49 orang $(48 \%)$.
Responden yang pernah mengalami kecelakaan akibat kerja adalah $44(43,1 \%)$ orang dan beberapa dari responden tersebut mengalami kecelakaan yang lebih dari satu kali. Kejadian tertusuk jarum suntik menunjukkan angka sebesar 58 kasus dan merupakan kecelakaan yang paling banyak dialami oleh responden (39\%).

Pernyataan-pernyataan yang diberikan kepada responden, setelah dilakukan analisis, ada beberapa pernyataan yang memiliki hubungan yang bermakna yaitu pernyataan "Kesakitan akibat paparan yang kecil dari suara bising." ( $p=$ $\left.0,032, \mathrm{X}^{2}=8,16\right)$, "Tidak ada pengaruh kecelakaan akibat kerja yang permanen terhadap kesehatan." $\left(p=0,044, X^{2}=7,89\right)$, dan "Mengetahui waktu penggunaan alat pelindung diri ketika terpapar bahaya." $(\mathrm{p}=0,023, \mathrm{X} 2=9,56)$.

Tabel 1 Dekripsi Karakteristik Umum Tenaga Kesehatan

\begin{tabular}{|c|c|c|}
\hline Karakteristik & $\mathbf{N}$ & $\%$ \\
\hline \multicolumn{3}{|l|}{ Jenis Kelamin } \\
\hline Laki-laki & 6 & $5,9 \%$ \\
\hline Perempuan & 96 & $94,1 \%$ \\
\hline Usia (tahun) & 78 & $76,5 \%$ \\
\hline$<35$ & 24 & $23,5 \%$ \\
\hline \multicolumn{3}{|l|}{$\geq 35$} \\
\hline \multicolumn{3}{|l|}{ Pengalaman kerja (tahun) } \\
\hline Median & 6 & \\
\hline Rentang & $1-27$ & \\
\hline \multicolumn{3}{|l|}{ Pendidikan } \\
\hline Diploma & 81 & $79,4 \%$ \\
\hline Strata 1 & 20 & $19,6 \%$ \\
\hline Strata 2 & 1 & $1 \%$ \\
\hline \multicolumn{3}{|l|}{ Profesi } \\
\hline Dokter Umum & 1 & $1 \%$ \\
\hline Bidan & 47 & $46,1 \%$ \\
\hline Perawat & 45 & $44,1 \%$ \\
\hline Analis/Pranata & 9 & $8,8 \%$ \\
\hline \multicolumn{3}{|l|}{ Unit Pelayanan } \\
\hline Gawat Darurat & 8 & $7,8 \%$ \\
\hline Instalasi Persalinan & 15 & $14,7 \%$ \\
\hline Laboratorium & 9 & $8,8 \%$ \\
\hline Rawat Inap & 51 & $50 \%$ \\
\hline Rawat Intensif & 10 & $9,8 \%$ \\
\hline Rawat Jalan & 8 & $7,8 \%$ \\
\hline Pelatihan APD & 49 & $48 \%$ \\
\hline Pengalaman kecelakaan & 44 & $43,1 \%$ \\
\hline
\end{tabular}




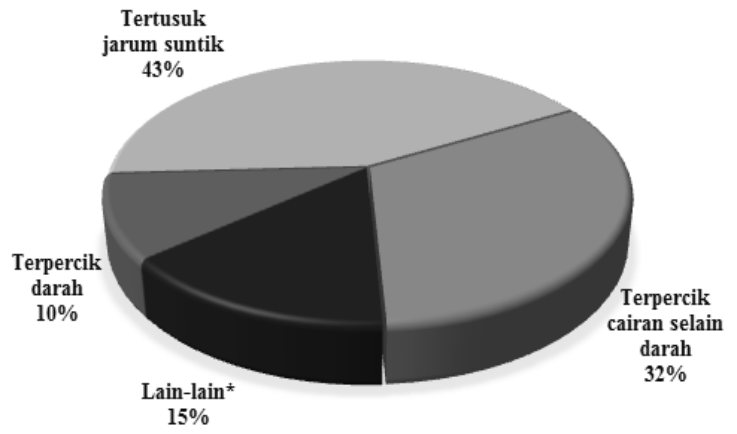

Keterangan : Lain-lain: teriris benda tajam, mata tersemprot zat kimia, mata kemasukan benda asing, terpeleset, terjatuh, terbentur, terjepit, terkena benda panas

\section{Gambar 1 Distribusi Kejadian Kecelakaan akibat Kerja di Rumah Sakit}

Tabel 2 Komparasi Persepsi terhadap Penggunaan Alat Pelindung Diri dengan Kejadian Kecelakaan akibat Kerja.

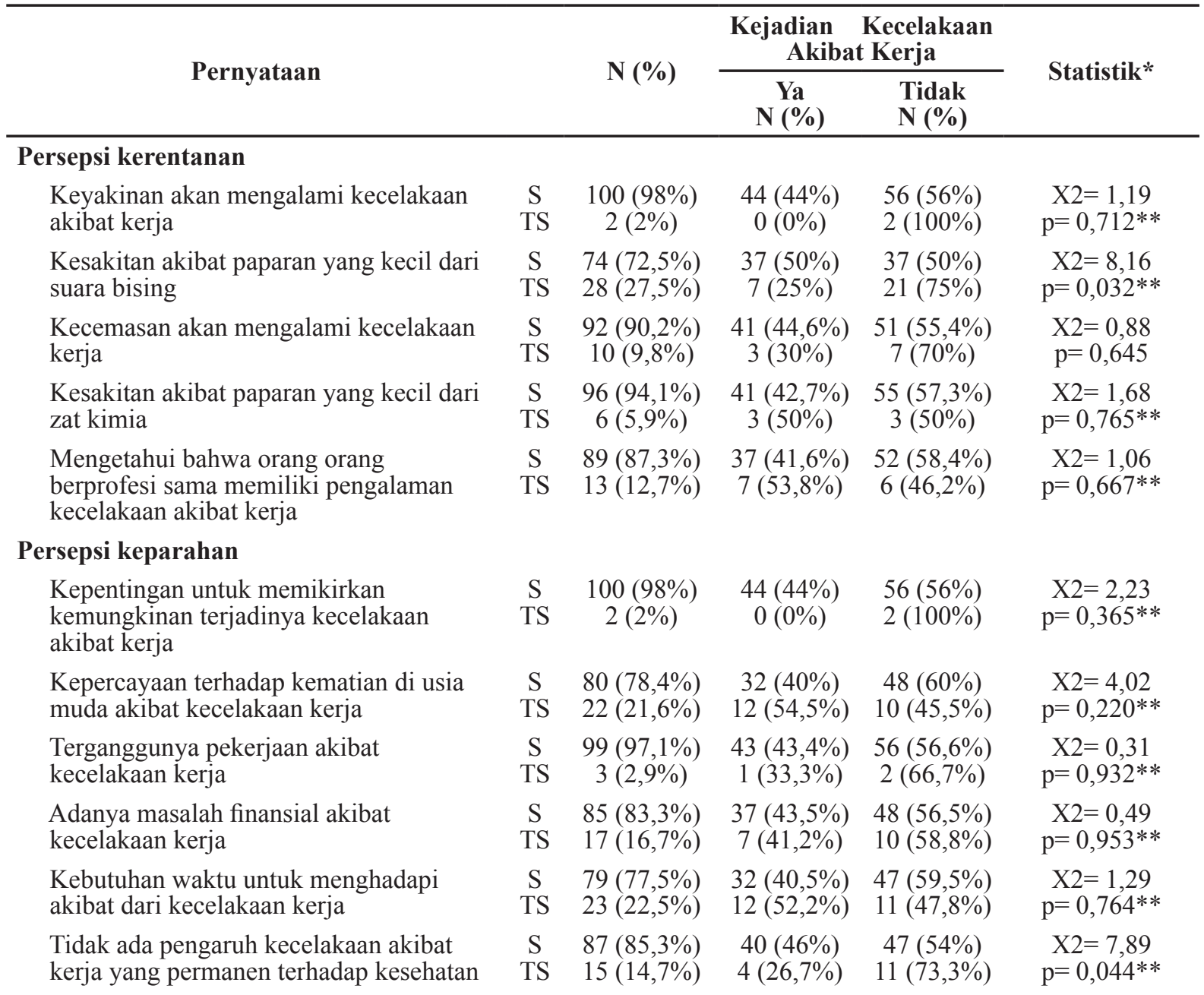




\section{Persepsi kebermanfaatan}

Penggunaan alat pelindung diri mencegah adanya gangguan kesehatan akibat kecelakan kerja

Kebermanfaatan penggunaan alat pelindung diri

Penggunaan alat pelindung diri mencegah dari paparan segala jenis bahaya

Ketidakcemasan terhadap peluang kecelakaan akibat kerja karena menggunakan alat pelindung diri

\section{Persepsi hambatan}

Penggunaan alat pelindung diri tidak merepotkan

Penggunaan alat pelindung diri bukan merupakan tindakan yang berlebihan

Penggunaan alat pelindung diri tidak menganggu kelancaran pekerjaan

Tidak sulit untuk mengubah kebiasaan dalam penggunaan alat pelindung diri

Tersedianya alat pelindung diri

Kepedulian atasan terhadap pelanggaran aturan penggunaan alat pelindung diri

\section{Persepsi isyarat untuk bertindak}

Pengawasan atasan dapat memperbaiki terhadap cara penggunaan alat pelindung diri yang benar

Kepentingan edukasi terhadap penggunaan alat pelindung diri yang benar

Kesadaran akan pentingnya penggunaan alat pelindung diri

Kepentingan rekan kerja sebagai pengingat dalam penggunaan alat pelindung diri

Kepentingan kampanye atau program keselamatan kerja dalam penggunaan alat pelindung diri

Keyakinan penggunaan alat pelindung diri dalam situasi dan lokasi yang berbahaya

Kedisiplinan dalam penggunaan alat pelindung diri

Kepentingan poster sebagai pengingat dalam penggunaan alat pelindung diri

\section{Persepsi keefektifan diri}

Pemberian contoh yang benar oleh atasan terhadap penggunaan alat pelindung diri

Pencegahan terhadap kejadian kecelakaan akibat kerja

Mengetahui waktu penggunaan alat pelindung diri ketika terpapar bahaya

$\begin{array}{ccccc}\text { S } & 102(100 \%) & 44(43,1 \%) & 58(56,9 \%) & \mathrm{X} 2=2,39 \\ \text { TS } & 0(0 \%) & 0(0 \%) & 0(0 \%) & \mathrm{p}=0,122 \\ & & & & \\ \mathrm{~S} & 102(100 \%) & 44(43,1 \%) & 58(56,9 \%) & \mathrm{X} 2=0,1 \\ \mathrm{TS} & 0(0 \%) & 0(0 \%) & 0(0 \%) & \mathrm{p}=0,920 \\ \mathrm{~S} & 96(94,1 \%) & 41(42,7 \%) & 55(57,3 \%) & \mathrm{X} 2=2.41 \\ \mathrm{TS} & 6(5,9 \%) & 3(50 \%) & 3(50 \%) & \mathrm{p}=0,481 * * \\ \mathrm{~S} & 61(59,8 \%) & 27(44,3 \%) & 34(55,7 \%) & \mathrm{X} 2=5,07 \\ \mathrm{TS} & 41(40,2 \%) & 17(41,5 \%) & 24(58,5 \%) & \mathrm{p}=0,169 * *\end{array}$

$\begin{array}{ccccc}\mathrm{S} & 93(91,2 \%) & 39(41,9 \%) & 54(58,1 \%) & \mathrm{X} 2=0,89 \\ \mathrm{TS} & 9(8,8 \%) & 5(55,6 \%) & 4(44,4 \%) & \mathrm{p}=0,641 \\ \mathrm{~S} & 101(99 \%) & 43(42,6 \%) & 58(57,4 \%) & \mathrm{X} 2=1,67 \\ \mathrm{TS} & 1(1 \%) & 1(100 \%) & 0(0 \%) & \mathrm{p}=0,410^{* *} \\ \mathrm{~S} & 95(93,1 \%) & 43(45,3 \%) & 52(54,7 \%) & \mathrm{X} 2=4,98 \\ \mathrm{TS} & 7(6,9 \%) & 1(14,3 \%) & 6(85,7 \%) & \mathrm{p}=0,157 * * \\ \mathrm{~S} & 90(88,2 \%) & 40(44,4 \%) & 50(55,6 \%) & \mathrm{X} 2=4,6 \\ \mathrm{TS} & 12(11,8 \%) & 4(33,3 \%) & 8(66,7 \%) & \mathrm{p}=0,168 * * \\ \mathrm{~S} & 87(85,3 \%) & 35(40,2 \%) & 52(59,8 \%) & \mathrm{X} 2=2,71 \\ \mathrm{TS} & 15(14,7 \%) & 9(60 \%) & 6(40 \%) & \mathrm{p}=0,437 * * \\ \mathrm{~S} & 93(91,2 \%) & 40(43 \%) & 53(57 \%) & \mathrm{X} 2=0,95 \\ \mathrm{TS} & 9(8,8 \%) & 4(44,4 \%) & 5(55,6 \%) & \mathrm{p}=0,975^{* *}\end{array}$

S $74(72,5 \%) \quad 32(43,2 \%) \quad 42(56,8 \%) \quad \mathrm{X} 2=6,58$

TS $28(27,5 \%) \quad 12(42,9 \%) \quad 16(57,1 \%) \quad \mathrm{p}=0,080 * *$

S $100(98 \%) \quad 43(43 \%) \quad 57(57 \%) \quad X 2=1,99$

TS $2(2 \%) \quad 1(50 \%) \quad 1(50 \%) \quad \mathrm{p}=0,849 * *$

S $100(98 \%) \quad 42(42 \%) \quad 58(58 \%) \quad \mathrm{X} 2=3,99$

TS $2(2 \%) \quad 2(100 \%) \quad 0(0 \%) \quad \mathrm{p}=0,088 * *$

S $93(91,2 \%) \quad 42(45,2 \%) \quad 51(54,8 \%) \quad \mathrm{X} 2=4,54$

TS $\quad 9(8,8 \%) \quad 2(22,2 \%) \quad 7(77,8 \%) \quad \mathrm{p}=0,165^{* *}$

S $97(95,1 \%) \quad 42(43,3 \%) \quad 55(56,7 \%) \quad X 2=1,32$

TS $5(4,9 \%) \quad 2(40 \%) \quad 3(60 \%) \quad \mathrm{p}=0,586^{* *}$

S $101(99 \%) \quad 43(42,6 \%) \quad 58(57,4 \%) \quad X 2=2,24$

TS $\quad 1(1 \%) \quad 1(100 \%) \quad 0(0 \%) \quad \mathrm{p}=0,304 * *$

S $100(98 \%) \quad 43(43 \%) \quad 57(57 \%) \quad \mathrm{X} 2=5,82$

TS $2(2 \%) \quad 1(50 \%) \quad 1(50 \%) \quad \mathrm{p}=0,056^{* *}$

S $\quad 96(94,1 \%) \quad 42(43,8 \%) \quad 54(56,2 \%) \quad \mathrm{X} 2=0,44$

TS $6(5,9 \%) \quad 2(33,3 \%) \quad 4(66,7 \%) \quad \mathrm{p}=0,794 * *$

$\begin{array}{ccccc}\text { S } & 91(89,2 \%) & 40(44 \%) & 51(56 \%) & \mathrm{X} 2=5,59 \\ \text { TS } & 11(10,8 \%) & 4(36,4 \%) & 7(63,6 \%) & \mathrm{p}=0,124 * * \\ \mathrm{~S} & 98(96,1 \%) & 41(41,8 \%) & 57(58,2 \%) & \mathrm{X} 2=3,07 \\ \mathrm{TS} & 4(3,9 \%) & 3(75 \%) & 1(25 \%) & \mathrm{p}=0,209 * * \\ \mathrm{~S} & 57(55,9 \%) & 24(42,1 \%) & 33(57,9 \%) & \mathrm{X} 2=9,56 \\ \mathrm{TS} & 45(44,1 \%) & 20(44,4 \%) & 25(55,6 \%) & \mathrm{p}=0,023\end{array}$


Keyakinan untuk bisa menggunakan alat pelindung diri dalam situasi yang mendesak

Keyakinan dapat memilih jenis alat pelindung diri yang tepat

Keyakinan terhadap perlindungan diri dari paparan bahaya karena penggunaan alat pelindung diri

Keyakinan bahwa penggunaan alat pelindung diri tidak menganggu kinerja/ prestasi kerja

$\begin{array}{ccccc}\text { S } & 75(73,5 \%) & 30(40 \%) & 45(60 \%) & \mathrm{X} 2=5,38 \\ \text { TS } & 27(26,5 \%) & 14(51,9 \%) & 13(48,1 \%) & \mathrm{p}=0,142 * * \\ & & & & \\ \text { S } & 92(90,2 \%) & 43(46,7 \%) & 49(53,3 \%) & \mathrm{X} 2=5,7 \\ \text { TS } & 10(9,8 \%) & 1(10 \%) & 9(90 \%) & \mathrm{p}=0,054 * * \\ & & & & \\ \mathrm{~S} & 100(98 \%) & 44(44 \%) & 56(56 \%) & \mathrm{X} 2=1,68 \\ \text { TS } & 2(2 \%) & 0(0 \%) & 2(100 \%) & \mathrm{p}=0,445 * * \\ & & & & \\ \text { S } & 84(82,4 \%) & 40(47,6 \%) & 44(52,4 \%) & \mathrm{X} 2=3,76 \\ \text { TS } & 18(17,6 \%) & 4(22,2 \%) & 14(77,8 \%) & \mathrm{p}=0,295 *\end{array}$

*Uji Chi-square, **Uji Fisher

$\mathrm{S}=$ Setuju

$\mathrm{TS}=$ Tidak Setuju

Tabel 3 Korelasi 6 kelompok Persepsi terhadap Penggunaan Alat Pelindung Diri dengan Kejadian Kecelakaan Akibat Kerja

\begin{tabular}{lcc}
\hline \multicolumn{1}{c}{ Kelompok persepsi } & Nilai p* & r \\
\hline Persepsi Kerentanan & 0,940 & $-0,008$ \\
Persepsi Keparahan & 0,760 & $-0,031$ \\
Persepsi Kebermanfaatan & 0,719 & $-0,036$ \\
Persepsi Hambatan & 0,136 & $-0,149$ \\
Persepsi Isyarat untuk Bertindak & 0,984 & 0,002 \\
Persepsi Keefektifan Diri & 0,536 & 0,062 \\
\hline
\end{tabular}

*Uji Spearmen Correlation

Tabel 4 Hubungan antara Persepsi terhadap Penggunaan Alat Pelindung Diri dengan Kejadian Kecelakaan Akibat Kerja

\begin{tabular}{lcc}
\hline & Nilai $\mathbf{p}^{*}$ & $\mathbf{r}$ \\
\hline $\begin{array}{l}\text { Hubungan antara persepsi terhadap } \\
\text { penggunaan alat pelindung diri } \\
\text { dengan kejadian kecelakaan akibat }\end{array}$ & 0,395 & $-0,085$ \\
kerja & & \\
\hline
\end{tabular}

*Uji Spearmen Correlation

Komparasi 6 kelompok persepsi dapat disimpulkan bahwa persepsi keefektifan diri memiliki nilai peringkat terjadinya kecelakaan kerja yang lebih tinggi daripada tidak terjadinya kecelakaan kerja $(\mathrm{ya}=51,95$, tidak $=51,16)$, sedangkan 5 kelompok persepsi lainnya memiliki nilai peringkat terjadinya kecelakaan kerja yang lebih rendah daripada tidak terjadinya kecelakaan kerja. Selain itu, tidak ada persepsi yang memiliki hubungan yang signifikan dengan kejadian kecelakaan akibat kerja.

Persepsi tenaga kesehatan terhadap penggunaan alat pelindung diri tidak terdapat hubungan yang bermakna dengan kejadian kecelakaan akibat kerja dalam penelitian ini, dengan nilai p lebih besar dari 0,05 dan kekuatan korelasinya sangat lemah dan dapat diabaikan serta nilai arah korelasinya negatif.

\section{Pembahasan}

Health Belief Model merupakan teori yang dikembangkan dari tahun 1950 oleh psikologis sosial di Pelayanan Kesehatan Masyarakat United Satated. Teori ini berkembang dari dua sumber yaitu Stimulus Response (S-R) Theory dan Cognitive Theory yang menyatakan bahwa kebiasaan memengaruhi ekspetasi individu terhadap situasi tertentu termasuk menjauhi kesakitan atau mendapatkan kesehatan dan berharap tindakan kesehatan tertentu dapat 
mencegah kesakitan. ${ }^{8}$

Teori ini terdiri dari 6 kunci konsep yaitu persepsi kerentanan, persepsi keparahan, persepsi kebermanfaatan, persepsi hambatan, persepsi isyarat untuk bertindak dan persepsi keefektifan diri yang digunakan dalam penelitian ini sebagai variabel bebas untuk melihat persepsi terhadap penggunaan alat pelindung diri. ${ }^{9}$

Alat pelindung diri merupakan suatu alat yang memiliki kemampuan untuk melindungi seseorang dengan menutupi/menghambat sebagian atau seluruh tubuh dari potensi bahaya seperti fisik, kimia, biologik, ergonomik dan psikososial di tempat kerja sehingga mengurangi risiko kecelakaan akibat kerja dan menncegah terjadinya infeksi dan penyakit akibat paparan berbagai macam bahaya., ${ }^{2,13}$ Alat-alat pelindung diri yang sering digunakan di Rumah Sakit adalah apron, masker, sarung tangan, sepatu boot, tutup kepala dan kaca mata google. Potensi-potensi bahaya tersebut dapat mengakibatkan kecelakaan kerja seperti teriris benda tajam, tertusuk jarum suntik, tepercik dengan darah, terpercik cairan tubuh lain (urin), terjatuh, terpeleset dan lainlain. $5,6,7,10,11,12$

Penelitian ini menyimpulkan kecelakaan yang sering terjadi di rumah sakit tersebut yaitu tertusuk jarum suntik (39\%) ketika melakukan prosedur pengambilan darah dan pemasangan infus, terpercik cairan selain darah $(30 \%)$ saat membuang urin pasien dan terpercik darah $(10 \%)$. Kejadian kecelakaan kerja tersebut dianalis untuk mengetahui hubungannya dengan penggunaan alat pelindung diri. Data tidak terdistribusi dengan normal dan jumlah responden yang tidak memenuhi jumlah sampel minimum $(102<116)$ dilakukan analisis, sehingga dapat disimpulkan bahwa tidak terdapat hubungan yang signifikan antara persepsi penggunaan alat pelindung diri dengan kejadian kecelakaan akibat kerja $(\mathrm{r}=$ $-0,085, \mathrm{p}=0,395)$. Penelitian yang dilakukan oleh Sri Yusnita di Rumah Sakit Pendidikan juga menunjukkan bahwa tidak terdapat hubungan yang signifikan antara kejadian kecelakaan akibat kerja akibat benda tajam dan sikap terhadap universal precaution, begitu juga dengan persepsi kepatuhan terhadap penggunaan universal precaution. ${ }^{7}$

Penelitian ini juga dilakukan komparasi antara persepsi tenaga kesehatan terhadap penggunaan alat pelindung diri dengan pernah tidaknya responden mengalami kecelakaan akibat kerja. Pernyataan-pernyataan yang diberikan kepada responden, setelah dilakukan analisis ada beberapa pernyataan yang memiliki hubungan yang bermakna yaitu pernyataan "Kesakitan akibat paparan yang kecil dari suara bising." ( $p=$ $0,032, \mathrm{X} 2=8,16)$, "Tidak ada pengaruh kecelakaan akibat kerja yang permanen terhadap kesehatan." $\left(p=0,044, X^{2}=7,89\right)$, dan "Mengetahui waktu penggunaan alat pelindung diri ketika terpapar bahaya." $\left(p=0,023, X^{2}=9,56\right)$.

Penelitian sebelumnya menyatakan bahwa pengetahuan terhadap risiko terpaparnya berbagai bahaya selama bekerja membantu individu dalam melakukan tindakan tertentu, tetapi masih ada tenaga kesehatan yang tidak perduli karena menganggap hal tersebut tidak penting atau tidak memahami prosedur yang harus dilakukan. Selain itu, individu yang berusia $<35$ tahun yang memperoleh pelatihan, persepsi yang rendah terhadap hambatan, dan persepsi terhadap infrastruktur serta lingkungan tempat kerja yang aman mempengaruhi kepatuhan dalam penggunaan alat pelindung diri..$^{14,15}$

Responden dalam penelitian ini mayoritas berumur $<35$ tahun $(76,5 \%)$ dan mengikuti pelatihan alat pelindung diri $(48 \%)$ dan tidak terdapat hubungan persepsi hambatan dalam penggunaan alat pelindung diri dengan kecelakan akibat kerja $(\mathrm{r}=-0,149, \mathrm{p}=0,136)$ (Tabel. 3). Keseluruhan pernyataan dalam persepsi hambatan disetujui oleh lebih dari $80 \%$ responden dan responden yang tidak mengalami kecelakaan lebih dari setengah responden $(>50 \%)$. Jadi, tingginya persepsi hambatan (pernyataan negatif) terhadap penggunaan alat pelindung diri mengurangi risiko kejadian kecelakaan akibat kerja. Penelitian lain juga mengatakan bahwa persepsi hambatan untuk impelementasi universal precaution setara dengan rendahnya suplai alat pelindung diri $(73 \%)$ dan bekerja di ruang darurat. ${ }^{5}$ Namun, penelitian ini tidak menganalisis hubungan antara usia, unit pelayanan, suplai dan pelatihan alat pelindung diri dengan kejadian kecelakaan kerja.

Faktor lain yang tidak diteliti dalam penelitian ini tetapi memengaruhi individu mengalami kecelakaan kerja, diantaranya kesadaran, durasi kerja dan kelelahan. Kesadaran (terbangun atau tidak mengantuk) mengurangi risiko terjadinya kecelakaan. ${ }^{15,16}$ Durasi kerja yang lebih dari 12 jam lebih memiliki risiko kecelakaan yang tinggi daripada durasi kerja kurang dari 12 jam. Risiko kecelakaan terbesar terjadi pada durasi kerja selama 24 jam. Jadi, semakin lama durasi kerja maka semakin tinggi risiko kecelakaan dan penyakit pada sampel yang bekerja di pelayanan kesehatan darurat. ${ }^{17}$

Kelelahan dapat memengaruhi seseorang dalam melakukan suatu tindakan. Penelitian yang dilakukan di Rumah Sakit Pendidikan Italia mengatakan bahwa kelelahan memiliki hubungan yang bermakna dengan risiko kecelakaan. Selain itu, tempat kerja yang memliki paparan dengan darah juga memiliki hubungan dengan risiko kejadian kecelakaan kerja. ${ }^{18}$ 
Keterbatasan dalam penelitian ini adalah jumlah sampel yang tidak memenuhi jumlah sampel minimum karena pengisian responden yang tidak lengkap dan menolak untuk mengikuti penelitian ini. Kemungkinan proses pengisian kuesioner menimbulkan pertanyaan bagi responden sehingga tidak diisi dengan sebenarnya seperti pengisian kuesioner jenis-jenis kecelakaan. Faktor-faktor lain yang berkaitan dengan kejadian kecelakaan kerja dapat menjadi variabel tambahan (confounding variable) dan memengaruhi hasil analisis data, tetapi tidak dimasukkan ke dalam variabel penelitian, seperti usia, pengetahuan, pelatihan, suplai alat pelindung diri, kesadaran, durasi kerja dan kelelahan. Selain itu, penelitian dengan desain potong lintang tidak dapat menunjukkan kronologi terjadinya sebab-akibat antar-variabel.

Penelitian ini menunjukkan tidak terdapat hubungan yang bermakna antara persepsi tenaga kesehatan terhadap penggunaan alat pelindung diri dengan kejadian kecelakaan akibat kerja. Namun, kepatuhan terhadap penggunaan alat pelindung diri merupakan hal yang harus diperhatikan oleh pihak rumah sakit. Rumah sakit dapat mempertegas prosedur operasional standar dan memberikan pelatihan kepada seluruh tenaga kesehatan dalam penggunaan alat pelindung diri $(100 \%)$ serta memiliki suplai alat pelindung diri yang memadai untuk meningkatkan pengetahuan dan kepercayaan serta tindakan tenaga kesehatan terhadap pentingnya kesehatan dan keselamatan kerja di rumah sakit. Selain itu, penelitian lebih lanjut direkomendasikan untuk mengevaluasi mengenai faktor-faktor lain yang dapat memengaruhi kejadian kecelakaan akibat kerja terhadap tenaga kesehatan baik di Pusat Pelayanan Kesehatan (PPK) tingkat satu, PPK tingkat dua, maupun PPK tingkat tiga, sehingga dapat dijadikan sebagai gambaran dalam penyusunan strategi untuk peningkatan kesehatan dan keselamatan kerja bagi tenaga kesehatan di rumah sakit

\section{Daftar Pustaka}

1. Presiden RI. Undang-Undang RI Nomor 36 Tahun 2014 tentang Tenaga Kesehatan. Jakarta; 2014.

2. Kemenkes RI. Keputusan Kemenkes RI Nomor1087/MENKES/SK/VIII/2010 tentang Standar Kesehatan dan Keselamtan Kerja di Rumah Sakit. Jakarta; 2010.

3. WHO. Health workers occupational health. World Health Organization; 2010. Tersedia dari:http://www.who.int/occupationalhealth/ topics/hcworkers/en/.

4. WHO. Health-care waste. World Health
Organization;2015. Tersedia dari:http://www. who.int/mediacentre/factsheets/fs253/en/

5. Jahangiri M, Rostamabadi A, Hoboubi N, Tadayon N, Soleimani A. Needle Stick Injuries and their Related Safety Measures among Nurses in a University Hospital, Shiraz, Iran. Saf Health Work. Elsevier Ltd; 2015;7(1):72-7.

6. Ibrahim K. Nurses' Knowledge, Attitudes, and Practices of Universal Precaution Toward HIV/AIDs Transmission in a District Hospital West Java Province, Indonesia. Unpad Repository; 2013.

7. Sari SYI, Ibrahim K, Haroen H, Afriandi I, Sunjaya DK, Hinduan ZR, dkk. Knowledge, Attitude and Perceived Adherence with Universal Precautions among Health care workers in the Obstetrics and Gynaecology Department of an Indonesian Teaching Hospital. Int J Infect Control; 2011;(38):1-7.

8. Wall JM. Development of A Health Belief Model Based Instrument to Assess Worker Beliefs about Using Personal Protective Equipment. University of Utah; 2009.

9. Champion VL. The Health Belief Model. Health Behaviour and Health Education. 4th ed. United States of America: Jossey-Bass; 2008. hal. 45-62

10. Nouetchognou JS, Ateudjieu J, Jemea B, Mbanya D. Accidental Exposures to Blood and Body Fluids among Health care workers in a Referral Hospital of Cameroon. BMC Res Notes. BioMed Central; 2016;9(1):94.

11. Parubak M, Djajakusli R, Russeng SS. Studi Kecelakaan Kerja pada Petugas Kesehatan RS Elim Rantepao dan RSUD Lakipadada Makale Kebupaten Tana Toraja. MKMI. 2009;5(4):82-8.

12. Mega HWR. Gambaran Kejadian Luka Benda Tajam Pada Perawat RSUD Dr. M. Haulussy Amvon. Universitas Hasanuddin; 2012.

13. Menteri Tenaga Kerja dan Transmigrasi RI. Peraturan Menteri Tenaga Kerja dan Transmigrasi Republik Indonesia Nomor PER.08/MEN/VII/2010 tentang Alat Pelindung Diri. Jakarta; 2010.

14. Chia SE, Koh D, Fones C, Qian F, Muttakin Z, Emmanuel S, dkk. Appropriate Use of Personal Protective Equipment among Healthcare workers in Public Sector Hospitals and Primary Healthcare Polyclinics during the SARS Outbreak in Singapore. Occup Environ Med; 2005;(April 2003);62:473477.

15. Maria A, Victor E, Elaine S, Gir E. Individual, Work-related and Institutional Factors Associated with Adherence to Standard Precautions. J Infect Control; 2013;2(2):106- 
Atri Laranova : Persepsi Tenaga Kesehatan terhadap Penggunaan Alat Pelindung Diri dan Kejadian Kecelakaan Akibat Kerja di Salah Satu Rumah Sakit di Kota Bandung

111.

16. Valent F, Sincig E, Gigli GL, Dolso P. Maintenance of Wakefulness and Occupational Injuries among Workers of an Italian Teaching Hospital. Saf Health Work. Elsevier Ltd; 2016;7(2):120-3.

17. Weaver MD, Patterson PD, Fabio A, Moore CG, FreibergMS, SongerTJ.AnObservational Study of Shift Length, Crew Familiarity, and occupational Injury and Illness in Emergency Medical Services Workers. Occup Environ Med;2015;72(11):798-804.

18. Valent F, Mariuz M, Liva G, Bellomo F, Corti DD, Degan S, dkk. A Case-crossover Study of Sleep, Fatigue, and other Transient Exposures at Workplace and the Risk of Non-Fatal Occupational Injuries among the Employees of an Italian Academic Hospital. IJOMEH; 2016;29(6):1001-9. 